\title{
Chlorhexidine to treat oral mucositis in patients with acute leukemia: systematic review*
}

\author{
Uso da clorexidina no tratamento da mucosite oral em pacientes com leucemia aguda: revisão \\ sistemática
}

Rômulo Augusto de Paiva Macedo ${ }^{1}$, Everton Freitas de Morais², Afonso Nóbrega Dantas ${ }^{1}$, Maria de Lourdes Silva de Arruda Morais ${ }^{3}$

${ }^{*}$ Received from Potiguar University, Natal, RN, Brazil.

DOI 10.5935/1806-0013.20150044

\section{ABSTRACT}

BACKGROUND AND OBJECTIVES: Leukemias impair hematopoietic stem-cells shunting and promote a proliferation of malignant cells without functional competence. Studies point that oral manifestations such as pain, hyperplasia and gum bleeding may be one of the first signs in leukemia patients. In light of the above, this study aimed at carrying out a systematic analysis of articles published in the last 15 years, with regard to chlorhexidine to treat and prevent mucositis in acute leukemia children under chemotherapy.

CONTENTS: A systematic search of articles published between January 2000 and January 2015 was carried out in Pubmed/ Medline, Science Direct and LILACS databases. After systematic search, 6 articles have fulfilled all methodological inclusion criteria. Chlorhexidine is an important means of preventing and treating oral mucositis and studies refer that $0.12 \%$ chlorhexidine gluconate effectiveness is probably related to its bactericide action. Adequate oral hygiene is important to prevent mucositis and other therapeutic modalities have shown to be effective to treat and prevent oral mucositis.

CONCLUSION: Chlorhexidine gluconate does not totally eliminate oral mucosa injuries, but is able to decrease their frequency and intensity without significant noxious effects. However, other drugs compared to chlorhexidine in this study may present better results.

Keywords: Chemotherapy, Hematology, Oncology, Oral manifestations, Mucositis.

1. Universidade Potiguar, Faculdade de Odontologia, Natal, RN, Brasil.

2. Universidade Potiguar, Faculdade de Odontologia, Bolsista de Iniciação a Pesquisa CNPq, Natal, RN, Brasil.

3. Universidade Federal do Rio Grande do Norte, Universidade Potiguar, Natal, RN, Brasil.

Submitted in May 01, 2015.

Accepted for publication in July 06, 2015.

Conflict of interests: none - Sponsoring sources: none.

\section{Correspondence to:}

Everton Freitas de Morais

Avenida Senador Salgado Filho, 1610 - Lagoa Nova

59056-000 Natal, RN, Brasil.

E-mal: evertonfreitas2@hotmail.com

(C) Sociedade Brasileira para o Estudo da Dor

\section{RESUMO}

JUSTIFICATIVA E OBJETIVOS: As leucemias comprometem a derivação das células-tronco hematopoiéticas e promovem uma proliferação de células malignas sem competência funcional. Estudos apontam que manifestaçóes orais como dor, hiperplasia e sangramento gengival podem ser um dos primeiros sinais em pacientes com leucemia. Diante do exposto, o objetivo deste estudo foi realizar uma análise sistemática de artigos publicados nos últimos 15 anos, no que diz respeito ao uso da clorexidina no tratamento e prevenção da mucosite em crianças com leucemia aguda em quimioterapia.

CONTEÚDO: Uma busca sistemática de artigos publicados entre janeiro de 2000 e janeiro de 2015 foi feita nas bases de dados Pubmed/Medline, Science Direct e LILACS. Após pesquisa sistemática 6 artigos preencheram todos os critérios de inclusão metodológica. A clorexidina é um importante meio de prevenção e tratamento da mucosite oral e estudos referem que a efetividade do gluconato de clorexidina a $0,12 \%$ está provavelmente relacionada à sua ação bactericida. A correta higienização oral tem importante papel na prevenção da mucosite e outras formas terapêuticas demonstram ser eficazes no tratamento e prevenção da mucosite oral.

CONCLUSÁO: O gluconato de clorexidina não elimina totalmente as lesôes de mucosa oral, mas é capaz de diminuir sua frequência e intensidade sem apresentar efeitos deletérios significativos no paciente. Entretanto, outros fármacos comparados à clorexidina nesteestudo podem apresentar melhores resultados. Descritores: Hematologia, Manifestaçóes bucais, Mucosite, Oncologia, Quimioterapia.

\section{INTRODUCION}

Leukemias impair hematopoietic stem-cells shunting and promote a proliferation of malignant cells without functional competence. There are different groups of lymphocytes, thus different types of leukemia, which are classified according to involved cell, disease duration and character ${ }^{1-4}$. Its etiology is still uncertain and might be related to factors such exposure to radiation and genetics ${ }^{3}$.

Acute lymphoid leukemia (ALL) represents approximately $80 \%$ of all leukemias affecting children and young adults, and acute myeloid leukemia (AML) is responsible for appro- 
ximately $15 \%$ of cases ${ }^{5,6}$. In childhood, most affected age is four years of age, being approximately twice as common in Caucasian patients as compared to non-Caucasians ${ }^{7,8}$. Studies show that oral manifestations such as pain, hyperplasia and gingival bleeding may be the first signs of leukemia patients ${ }^{4,9}$. Treatment of choice for this cancer is chemotherapy, which may be used together with other therapies ${ }^{10-12}$. In the last four decades, there has been major progress in the treatment of leukemia and approximately $80 \%$ of children and teenagers with early diagnosis may be cured ${ }^{8}$. However, several studies point to anticancer treatment as inducing oral mucositis ${ }^{1,2,4}$. Oral mucositis is characterized by erythema, followed by very painful ulcers in oral mucosa, which interfere with nutritional status and quality of life (QL), and may limit or even interrupt anticancer therapy in severe cases ${ }^{2}$.

Several studies indicate chlorhexidine gluconate, due to its antibacterial and antifungal activity and binding to tissue surfaces, to prevent and treat oral manifestations of such patients, especially mucositis ${ }^{2,13}$. However, they caution that there may be sequelae for patients with long-term use of chlorhexidine, such as burning sensation, dysgeusia and dental pigmentation $^{13}$.

The understanding of oral injuries caused by acute leukemias (AL) and anticancer therapies is dentists' duty, as well as the use of prophylactic and therapeutic measures to promote patients' oral health and help the return of their physical wellbeing.

In light of the above, this study aimed at carrying out a systematic analysis of articles published in the last 15 years with regard to the use of chlorhexidine to treat and prevent mucositis in AL children submitted to chemotherapy.

\section{CONTENTS}

A systematic search of articles published between January 2000 and January 2015 was carried out in Pubmed/Medline, Science Direct and LILACS databases, looking for studies evaluating the use of chlorhexidine to prevent and treat oral mucositis in AL patients.

The following terms were used for the search: Acute Leukemia, Oral Mucositis, Chlorhexidine, Treatment, Prevention, Oral Mucosa, as well as their synonyms and corresponding words in Portuguese and Spanish, in different combinations. Boolean operators AND, OR, NOT were used. Search strategies are shown in table 1 .
After getting the abstracts, three independent investigators have selected relevant studies according to inclusion and exclusion criteria. Inclusion criteria were original articles in English, Portuguese or Spanish, aiming at evaluating chlorhexidine to prevent and treat oral mucositis in AL patients; and articles published as of January 2000. Exclusion criteria were clinical cases, review articles, population outside research standards, articles published before 2000 or in different languages from those selected for the study.

The first selection stage was to evaluate titles and abstracts. Then, all studies the titles or abstracts of which were considered relevant to the subject where obtained in whole and completely analyzed. At the end, articles analyzed and selected by evaluators after consensus meeting were included in this review.

After initial search, 15 studies had potential to be included in this study, however after detailed and complete analysis, only 6 have met all methodological inclusion criteria ${ }^{13-18}$. Among selected studies, 5 were performed in developing countries ${ }^{13-15,17,18}$ and one in a developed country ${ }^{16}$. Methods and results of evaluated studies are shown in tables 2 and 3.

Participants' sample among selected studies has varied from 14 to 48 patients, in a total of 160 participants. Four studies were performed primarily in children between 2 and 15 years of age ${ }^{16,17}$. Most participants of the studies were above 15 years of age. Oral mucositis prevention and treatment with chlorhexidine gluconate were evaluated by 5 selected studies. Another study has evaluated chlorhexidine gluconate in children with ALL already with oral mucositis ${ }^{18}$.

Intraoral exam was used to evaluate patients of selected studies. Studies ${ }^{14,16}$ have used microbiological tests. Pereira Pinto et al. ${ }^{13}$ also used cytological exam. Aiming at evaluating pain level of patients, authors ${ }^{16,18}$ have used questionnaires applied to participants.

Chlorhexidine gluconate concentration was $0.12 \%$, except for the study by Mehdipour et al. ${ }^{17}$ the concentration of which was $0.2 \%$. Three studies had control group without treatment ${ }^{13,15,17}$. Choi \& Kim $^{16}$ have compared chlorhexidine and sodium bicarbonate to treat oral mucositis and sodium bicarbonate has shown better results.

In the study of Mehdipour et al. ${ }^{17}$, zinc sulfate was compared to chlorhexidine with better results in early evaluations of the study; however there has been no statistically significant difference in the final analysis of the experiment which has lasted 1 month. Setiawan, Reniarti \& Oewen ${ }^{18}$, who analyzed the effi-

Table 1. Search strategies and number of articles found on databases

\begin{tabular}{|c|c|c|c|}
\hline Strategies & A & $\mathrm{B}$ & C \\
\hline Chlorhexidine / oral mucositis & 12 & 747 & 198 \\
\hline Chlorhexidine / oral mucositis / treatment / acute leukemia & 0 & 727 & 184 \\
\hline Chlorhexidine / oral mucositis / (treatment OR prevention) / acute leukemia & 0 & 733 & 185 \\
\hline Chlorhexidine / oral mucositis / (treatment OR prevention) / mucosa / acute leukemia & 0 & 531 & 37 \\
\hline Chlorhexidine / oral mucositis / (treatment AND prevention) / oral mucosa/ acute leukemia & 0 & 401 & 37 \\
\hline
\end{tabular}

A = LILACS; $\mathrm{B}$ = Science Direct; C = Pubmed/Medline. 
Table 2. Methods and objectives of selected studies

\begin{tabular}{|c|c|c|c|c|c|c|}
\hline Studies & Objectives & $\begin{array}{l}\text { Types } \\
\text { of leu- } \\
\text { kemia }\end{array}$ & $\mathrm{n} /$ age & Protocol & $\begin{array}{l}\text { Oral health evalu- } \\
\text { ation }\end{array}$ & Analyzed variables \\
\hline $\begin{array}{l}\text { Soares et } \\
\text { al. }{ }^{14}\end{array}$ & $\begin{array}{l}\text { Evaluate oral mu- } \\
\text { cosa changes and } \\
\text { qualitative microbi- } \\
\text { ota changes in chil- } \\
\text { dren with ALL under } \\
\text { chemotherapy, as } \\
\text { well as the use of } \\
012 \% \text { chlorhexidine } \\
\text { in such patients. }\end{array}$ & ALL & $17 / 2$ to 12 years. & $\begin{array}{l}\text { Chlorhexidine mouthwash for } 1 \\
\text { minute, twice a day ( } 30 \text { minutes } \\
\text { after lunch and after last meal) } \\
\text { for } 10 \text { days. }\end{array}$ & $\begin{array}{l}\text { Clinical exam } \\
\text { of oral mucosa } \\
\text { for detection of } \\
\text { oral lesions and } \\
\text { microbiological } \\
\text { test. }\end{array}$ & $\begin{array}{l}\text { Presence of mucosi- } \\
\text { tis; effects of } 0.12 \% \\
\text { chlorhexidine on oral } \\
\text { microbiota. }\end{array}$ \\
\hline $\begin{array}{l}\text { Costa et } \\
\text { al. } .^{15}\end{array}$ & $\begin{array}{l}\text { Check the effective- } \\
\text { ness of a preventive } \\
\text { oral protocol using } \\
0.12 \% \text { chlorhexi- } \\
\text { dine mouthwashes } \\
\text { in children with ALL } \\
\text { submitted to anti- } \\
\text { cancer treatment. }\end{array}$ & ALL & $\begin{array}{l}14 / 2 \text { to } 10 \text { years. } \\
\text { ( } 7 \text { test group } / 7 \\
\text { control group). }\end{array}$ & $\begin{array}{l}\text { The experimental group re- } \\
\text { ceived supervised oral hy- } \\
\text { giene care and chlorhexidine } \\
\text { mouthwash twice a day. The } \\
\text { control group received super- } \\
\text { vised hygiene care with pla- } \\
\text { cebo mouthwash twice a day. } \\
\text { The experiment started } 1 \text { day } \\
\text { after and continued for up to } \\
10 \text { days after chemotherapy } \\
\text { induction phase. }\end{array}$ & $\begin{array}{l}\text { Clinical oral mu- } \\
\text { cosa exam. }\end{array}$ & $\begin{array}{l}\text { Evaluate the effect } \\
\text { of chlorhexidine to } \\
\text { treat oral manifesta- } \\
\text { tions; compare test } \\
\text { and control groups. }\end{array}$ \\
\hline $\begin{array}{l}\text { Choi \& } \\
\text { Kim }^{16}\end{array}$ & $\begin{array}{l}\text { Compare the ef- } \\
\text { ficacy of sodium } \\
\text { bicarbonate and } \\
\text { c h I o r h e x idine } \\
\text { mouthwash to pre- } \\
\text { vent oral manifesta- } \\
\text { tions in patients with } \\
\text { ALL during chemo- } \\
\text { therapy induction } \\
\text { phase }\end{array}$ & $\begin{array}{l}\text { ALL \& } \\
\text { AML }\end{array}$ & $\begin{array}{l}\text { 48/ Mean of } 38 \\
\text { years. (chlorhexi- } \\
\text { dine group }=24 \\
\text { patients; sodium } \\
\text { b i c a r b o n a t e } \\
\text { group }=24 \text { pa- } \\
\text { tients). }\end{array}$ & $\begin{array}{l}\text { Os participantes de ambos os } \\
\text { grupos foram orientados a rea- } \\
\text { lizar os bochechos } 4 \text { vezes ao } \\
\text { dia, sendo iniciados } 1 \text { dia antes } \\
\text { do início da quimioterapia até o } \\
\text { final da primeira fase do trata- } \\
\text { mento oncológico. }\end{array}$ & $\begin{array}{l}\text { Questionnaire, } \\
\text { clinical oral mu- } \\
\text { cosa exam and } \\
\text { microbiological } \\
\text { test. }\end{array}$ & $\begin{array}{l}\text { Presence of oral } \\
\text { lesions; effect of } \\
\text { mouthwashes on } \\
\text { oral mucosa. }\end{array}$ \\
\hline $\begin{array}{l}\text { Mehdipour } \\
\text { et al. }{ }^{17}\end{array}$ & $\begin{array}{l}\text { Evaluate the efficacy } \\
\text { of zinc oral antisep- } \\
\text { tic for chemothera- } \\
\text { py-induced oral mu- } \\
\text { cositis as compared } \\
\text { to chlorhexidine } \\
\text { mouthwash }\end{array}$ & AML & $\begin{array}{l}30 \quad(15 \quad \text { Test } / 15 \\
\text { control) } / \text { age } \\
\text { above } 15 \text { years. }\end{array}$ & $\begin{array}{l}\text { Induction and maintenance } \\
\text { phase patients were evaluated. } \\
\text { Patients of chlorhexidine and } \\
\text { zinc sulfate groups were ori- } \\
\text { ented to use mouthwash twice } \\
\text { a day during } 14 \text { days. Patients } \\
\text { were evaluated for } 8 \text { weeks. }\end{array}$ & $\begin{array}{l}\text { Clinical oral mu- } \\
\text { cosa exam. }\end{array}$ & $\begin{array}{l}\text { Compare patients } \\
\text { receiving } 0.2 \% \text { zinc } \\
\text { sulfate to patients } \\
\text { receiving } 0.2 \% \\
\text { chlorhexidine gluco- } \\
\text { nate to prevent oral } \\
\text { mucositis }\end{array}$ \\
\hline $\begin{array}{l}\text { Pereira } \\
\text { Pinto et } \\
\text { al. }^{13}\end{array}$ & $\begin{array}{l}\text { Evaluate clinical } \\
\text { aspects of oral mu- } \\
\text { cosa of children with } \\
\text { ALL and determine } \\
\text { the effect of } 0.12 \% \\
\text { chlorhexidine to } \\
\text { prevent oral com- } \\
\text { plications in these } \\
\text { patients. }\end{array}$ & LLA & $\begin{array}{l}33 \\
\text { Group I (23 chil- } \\
\text { dren): } \\
\text { Oral } 0.12 \% \\
\text { chlorhexidine so- } \\
\text { lution, } 2 X / \text { day, } \\
\text { group II (10 chil- } \\
\text { dren): not recei- } \\
\text { ving solution. /2 } \\
\text { to } 15 \text { years }\end{array}$ & $\begin{array}{l}\text { The experimental group had } \\
\text { chlorhexidine mouthwashes for } \\
1 \text { minute, twice a day ( } 30 \text { minu- } \\
\text { tes after lunch and after the last } \\
\text { meal) during } 10 \text { days. Control } \\
\text { group was not treated. }\end{array}$ & $\begin{array}{l}\text { Clinical oral ca- } \\
\text { vity exam / digi- } \\
\text { tal palpation of } \\
\text { oral mucosa and } \\
\text { cytological swa- } \\
\text { bs (obtained from } \\
\text { oral mucosa in } \\
\text { the beginning of } \\
\text { chemotherapy in- } \\
\text { tensification). }\end{array}$ & $\begin{array}{l}\text { Presence of mucosi- } \\
\text { tis; effects of } 0.12 \% \\
\text { chlorhexidine; com- } \\
\text { pare results among } \\
\text { study groups. }\end{array}$ \\
\hline $\begin{array}{l}\text { Setiawan, } \\
\text { Reniarti \& } \\
\text { Oewen }^{18}\end{array}$ & $\begin{array}{l}\text { Compare the ef- } \\
\text { fectiveness of } \\
\text { chlorhexidine gluco- } \\
\text { nate and povidone- } \\
\text { iodine mouthwash } \\
\text { for oral mucositis in } \\
\text { children receiving } \\
\text { chemotherapy for } \\
\text { ALL. }\end{array}$ & ALL & $18 / 2$ to 10 years & $\begin{array}{l}\text { Children developing mucositis } \\
\text { in the chemotherapy induction } \\
\text { phase were evaluated. Group } \\
\text { A received } 0.12 \% \text { chlorhexi- } \\
\text { dine, group B povidone-iodine, } \\
\text { group C saliva solution. Mouth- } \\
\text { washes were performed twice } \\
\text { a day (morning and evening) } \\
\text { being the protocol repeated } \\
\text { every day until injury remission } \\
\text { or for a maximum period of two } \\
\text { weeks. }\end{array}$ & $\begin{array}{l}\text { Clinical oral mu- } \\
\text { cosa exam. }\end{array}$ & $\begin{array}{l}\text { Evaluate the effects } \\
\text { of chlorhexidine } \\
\text { gluconate and povi- } \\
\text { done-iodine on oral } \\
\text { mucosa and com- } \\
\text { pare both to control } \\
\text { group. }\end{array}$ \\
\hline
\end{tabular}


Table 3. Results of studies selected for the research

\begin{tabular}{|c|c|c|c|}
\hline Studies & More frequent oral manifestations & $\begin{array}{l}\text { More frequent } \\
\text { manifestation } \\
\text { sites }\end{array}$ & Results \\
\hline $\begin{array}{l}\text { Soares et } \\
\text { al. } .^{14}\end{array}$ & $\begin{array}{l}\text { Mucositis was the most frequent oral manifestation } \\
\text { affecting } 5 \text { children. }\end{array}$ & $\begin{array}{l}\text { Not mentioned } \\
\text { in the study. }\end{array}$ & $\begin{array}{l}\text { Prophylactic use of } 0.12 \% \text { chlorhexidine gluconate } \\
\text { decreases the frequency of mucositis and oral patho- } \\
\text { gens in ALL children under chemotherapy. }\end{array}$ \\
\hline $\begin{array}{l}\text { Costa et } \\
\text { al. }^{15}\end{array}$ & $\begin{array}{l}\text { One experimental group (14.3\%) and one control } \\
\text { group }(71.4 \%) \text { child developed oral mucositis. }\end{array}$ & $\begin{array}{l}\text { Most frequent } \\
\text { in lip and jugal } \\
\text { mucosa. }\end{array}$ & $\begin{array}{l}\text { There has been significant decrease in the incidence } \\
\text { of mucositis and oral ulcers in children with prophy- } \\
\text { lactic chlorhexidine mouthwash. }\end{array}$ \\
\hline $\begin{array}{l}\text { Choie } \\
\mathrm{Kim}^{16}\end{array}$ & $\begin{array}{l}\text { Six }(25 \%) \text { patients of the sodium bicarbonate group } \\
\text { have developed mucositis versus } 15(62.5 \%) \text { of the } \\
\text { chlorhexidine group. }\end{array}$ & $\begin{array}{l}\text { Not mentioned } \\
\text { in the study. }\end{array}$ & $\begin{array}{l}\text { Sodium bicarbonate was more effective as compared } \\
\text { to chlorhexidine to fight oral mucositis. }\end{array}$ \\
\hline $\begin{array}{l}\text { Mehdipour } \\
\text { et al. }{ }^{17}\end{array}$ & $\begin{array}{l}\text { Frequency of mucositis varied according to exams } \\
\text { performed. } 1^{\text {st }} \text { exam }(0-\text { zinc sulfate } / 2 \text { chlorhexi- } \\
\text { dine); } 2^{\text {nd }} \text { exam ( } 3 \text { zinc sulfate } / 8 \text { chlorhexidine); } 3^{\text {rd }} \\
\text { exam ( } 5 \text { zinc sulfate } / 8 \text { chlorhexidine); } 4^{\text {th }} \text { exam ( } 3 \\
\text { zinc sulfate / } 6 \text { chlorhexidine) }\end{array}$ & $\begin{array}{l}\text { Not mentioned } \\
\text { in the study. }\end{array}$ & $\begin{array}{l}\text { Zinc sulfate was better to control oral mucositis as } \\
\text { compared to chlorhexidine in initial weeks, without } \\
\text { statistically significant difference in the last exam. }\end{array}$ \\
\hline $\begin{array}{l}\text { Pereira Pin- } \\
\text { to et al. }{ }^{13}\end{array}$ & $\begin{array}{l}\text { Mucositis was observed in six group I and eight } \\
\text { group II children and was characterized by the pres- } \\
\text { ence of edema, erythema and ulcers. }\end{array}$ & $\begin{array}{l}\text { Not mentioned } \\
\text { in the study. }\end{array}$ & $\begin{array}{l}\text { Chlorhexidine was beneficial in decreasing oral mani- } \\
\text { festations in children. }\end{array}$ \\
\hline $\begin{array}{l}\text { Setiawan, } \\
\text { Reniartie } \\
\text { Oewen }^{18}\end{array}$ & $\begin{array}{l}\text { All children had oral mucositis in the beginning of } \\
\text { the study. }\end{array}$ & $\begin{array}{l}\text { Not mentioned } \\
\text { in the study. }\end{array}$ & $\begin{array}{l}\text { The study showed that mucositis and related pain } \\
\text { presented remission in } 5 \text { to } 7 \text { days for the chlorhexi- } \\
\text { dine solution group, } 8 \text { to } 14 \text { days for the povidone- } \\
\text { iodine group and } 13 \text { to } 14 \text { days for the control group. }\end{array}$ \\
\hline
\end{tabular}

$\overline{A L L}=$ acute lymphoid leukemia.

Table 4. Chemotherapeutic agents and chemotherapy phases

\begin{tabular}{|c|c|}
\hline Studies & Chemotherapic agents \\
\hline Soares et al. ${ }^{14}$ & Combinations for chemotherapeutic treatment were not mentioned. \\
\hline $\begin{array}{l}\text { Costa et } \\
\text { al. }{ }^{15}\end{array}$ & $\begin{array}{l}\text { Therapy consisted of } 6 \text {-mercaptopurine (one } 50 / \mathrm{mg} / \mathrm{m} 2 / \text { day oral dose during six weeks), methotrexate (one } 2 \mathrm{mg} \text {;m2 } \\
\text { intravenous dose in continuous infusion during } 24 \mathrm{~h} \text { in days } 1,15,30 \text { and } 45 \text { of treatment, respectively), leucovorin (one } \\
15 \mathrm{mg} / \mathrm{m} 2 \text { oral dose four times a day in days } 2,3,16,17,31,32,46 \text { and } 47 \text { ) and spinal MADIT (combination of } 12 \mathrm{mg} \\
\text { methotrexate }+70 \mathrm{mg} \text { cytosine-arabinoside }+2 \mathrm{mg} / \mathrm{m} 2 \text { dexamethasone) in days } 1,15,30 \text { and } 45 \text {. }\end{array}$ \\
\hline Choie Kim ${ }^{16}$ & Under induction chemotherapy with idarubicin and enocitabine or LLA cyclophosphamide, vincristin and daunorubicin. \\
\hline Mehdipour et al. ${ }^{17}$ & Citarabine in the induction phase and novantrone in the consolidation phase. \\
\hline $\begin{array}{l}\text { Pereira Pinto et } \\
\text { al. } .^{13}\end{array}$ & $\begin{array}{l}\text { Protocol for acute leukemia treatment proposed by the Brazilian Society of Pediatric Oncology }{ }^{16} \text {. Methotrexate was a drug } \\
\text { used in this therapy. } 0.12 \% \text { chlorhexidine gluconate was administered for } 10 \text { consecutive days, after each methotrexate } \\
\text { infusion during intensification chemotherapy. }\end{array}$ \\
\hline $\begin{array}{l}\text { Setiawan, Reniar- } \\
\text { tie } \\
\text { Oewen }{ }^{18}\end{array}$ & $\begin{array}{l}\text { Methotrexate (one spinal dose in days } 1,14 \text { and } 42 \text { ), } \\
\text { Dexamethasone (one } 6 \mathrm{mg} / \mathrm{m} 2 / \text { day oral dose during } 5 \text { weeks), vincristin (one } 1.5 \mathrm{mg} / \mathrm{m} 2 \text { intravenous dose in continuous } \\
\text { infusion in } 5 \text { minutes in days } 7,14,21,28,35 \text { ), and L-asparaginase (one } 6000 \mathrm{ug} / \mathrm{m} 2 \text { intravenous dose in weeks } 4 \text { and } 5 \text { ). }\end{array}$ \\
\hline
\end{tabular}

MADIT = methotrexate, cytarabine and dexamethasone.

cacy of chlorhexidine and povidone-iodine to treat mucositis, have observed that the chlorhexidine group had faster lesion remission as compared to the second group.

With regard to oral mucosa site most affected by mucositis, only one study of Costa et al. ${ }^{15}$ has reported this frequency, being jugal mucosa and lip the sites reported by the authors. Chemotherapeutic drugs used during patients' follow-up period are shown in table 4 . Only the study by Soares et al. ${ }^{14}$ has not informed the chemotherapeutic scheme used for anticancer therapy. Selected studies are unanimous in stating that the stage with most oral mucositis affections is during induction and that adequate oral hygiene is critical for preventing oral lesions.

\section{DISCUSSION}

Primary treatment of choice for acute leukemias is chemotherapy, with protocols lasting more than one year ${ }^{19,20}$. This treatment is divided in phases which are induction, consolidation and maintenance. Maintenance phase is the longest treatment period and in which children have better clinical stability ${ }^{19,21}$. Induction phase is considered by the literature the phase with highest incidence of oral mucositis.

Three of selected studies for this review have used methotrexate in the induction phase ${ }^{13,15,18}$. Mucositis was more frequent between days 2 and 4 after beginning of treatment using intravenous methotrexate with mean remission times 
of 16 days, being the severity of oral lesions and their duration in children receiving chlorhexidine mouthwashes shorter as compared to control group ${ }^{15}$. Similar results were found by other studies ${ }^{13,22,23}$. According to Setiawan, Reniarti \& Oewen ${ }^{18}$, mucositis in general occurs between days 7 and 10 after beginning of treatment, especially in cases when methotrexate is used. Studies refer that the effectiveness of $0.12 \%$ chlorhexidine gluconate is probably related to its bactericide action.

In the literature, mucositis is related to chemotherapy agents' dose, administration type and interval, and such factors may vary according to the protocol used. So, it is understood that different protocols of the selected studies might have influenced the higher or lower incidence of oral mucositis, as well as the severity of the process, which significantly impairs a more judicious analysis.

In this review, all studies showed significant decrease in oral mucositis, as well as less severity and time of the disease with chlorhexidine digluconate, being its use indicated for prevention and treatment.

However, previous studies show that only with accurate oral hygiene it would be possible to prevent oral mucositis in leukemia patients ${ }^{22,23}$. It is known that poor oral cavity hygiene is another factor favoring local infections and, in addition, it is the entry point for systemic infections, impairing patients' general status and increasing their hospital stay. Adequate oral hygiene associated to prophylactic treatment of mucositis is paramount for the prevention of such oral lesion. According to these studies, it is understood that a good oral hygiene associated to chlorhexidine digluconate is able to decrease mucositis-induced pain in ALL children under anticancer treatment.

Among selected studies, three have compared chlorhexidine to other therapies. Setiawan, Reniart \& Oewen ${ }^{18}$ have compared povidone-iodine to chlorhexidine, being that the latter had better results to treat oral mucositis, with remission of 5 to 7 days versus 8 to 14 days for povidone-iodine. However, povidone-iodine had better results as compared to the control group using saliva solutions, which is in line with other studies $^{24,25}$. For the author, better chlorhexidine result may be related to the fact that it is absorbed by oral surfaces and released in mouth for a period of $24 \mathrm{~h}$, thus being in contact with the oral cavity for a longer time.

A study evaluating during four weeks chlorhexidine and zinc sulfate has observed better early results for zinc sulfate, however, in the fourth week, the difference between groups was not statistically significant. Zinc sulfate has positive effects on epithelization, is antioxidant and has antibacterial action, being effective for the maintenance of mucosal integrity and therapeutically acting during early mucositis stages ${ }^{17}$.

Choie \& $\mathrm{Kim}^{16}$ had better results with sodium bicarbonate as compared to chlorhexidine; however, at microbiological analysis, the number of micro-organisms in the oral cavity of patients using sodium bicarbonate was higher than of those using chlorhexidine, being this result similar to other stu$\operatorname{dies}^{26,27}$. According to the literature, the origin of oral mucosa lesions is directly related to anticancer treatment, being con- sequence of two major mechanisms: direct toxicity of the therapy on the mucosa and myelosuppression generated by the treatment $\mathrm{t}^{20}$, and its course may be influenced by infection. Alkaline solutions, water associated to sodium bicarbonate, change oral cavity $\mathrm{pH}$, inhibiting saliva acidity thus eliminating an environment prone to bacterial and fungal proliferation.

In the study by Soares et al. ${ }^{14}$, microbiological analysis has shown the presence of a small number of potentially pathogenic micro-organisms. Patients with oral mucositis had higher frequency of coagulase-negative staphylococcus $(80 \%)$ as compared to patients with normal oral mucosa (33.3\%). Labarca et al. ${ }^{28}$ point that the micro-organism associated to severe neutropenia may favor the onset of oral mucositis.

There are few studies in the literature aiming at evaluating the direct relationship between a specific drug used in chemotherapy and the incidence of oral mucositis. It is known, however, that chemotherapy agents more commonly associated to the development of oral mucositis are 5-fluoracil, methotrexate $^{29}$, cisplatin, bleomycin and doxorubicin ${ }^{30}$.

Selected studies for this review have not established correlation between chemotherapy schemes and frequency of oral mucositis among participants. The study by Mehdipour et al. ${ }^{17}$ has used cytarabine in the induction phase and novantrone in the consolidation phase, which are drugs seldom mentioned with regard to oral mucositis; however, its high incidence infers the need for carrying out studies to more deeply evaluate such correlation, as well as differences between chemotherapy schemes, lymphoid and myeloid leukemias and the onset of oral mucositis.

\section{CONCLUSION}

Chlorhexidine gluconate does not totally eliminate oral mucosa lesions, but is able to decrease their frequency and intensity without significant adverse effects for patients, decreasing pain and discomfort. However, other drugs compared to chlorhexidine may have better results, being important that further studies are carried out to better explain such effects.

\section{REFERENCES}

1. Subramaniam P, Babu KL, Nagarathna J. Oral manifestations in acute lymphoblastic leukemic children under chemotherapy. J Clin Pediatr Dent. 2008;32(4):319-24.

2. Morais EF, Lira JA, Macedo RA, Santos KS, Elias CT, Morais Mde L. Oral manifestations resulting from chemotherapy in children with acute lymphoblastic leukemia. Braz J Otorhinolaryngol. 2014;80(1):78-85

3. Hamerschlak N. Leukemia: genetics and prognostic factors. J Pediatr. 2008;84(4):52-7.

4. Silva LC, Carneiro FM, Cruz RA. Manifestaçôes bucais das leucemias agudas na infância. Arq Bras Odontol. 2008;4(1):40-54.

5. Ziegler DS, Dalla Pozza L, Waters KD, Marshall GM. Advances in childhood leukemia: successful clinical-trials research leads to individualized therapy. Med J Aust. 2005;182(2):78-81.

6. Costa SS, Silva AM, Macedo IA. Conhecimento de manifestaçóes orais da leucemia e protocolo de atendimento odontológico. Rev Odontol Univ São Paulo. 2011;23(1):70-8.

7. Galvão V, Castro $\mathrm{CH}$, Consolaro A. Mucosite severa em paciente com leucemia: uma abordagem terapêutica. Rev Cir Traumatol Buco-Maxilo-Fac. 2006;6(2):35-40.

8. Pui CH, Robison LL, Look AT. Acute lymphoblastic leukaemia. Lancet. 2008;371(9617):1030-43.

9. Carneiro FM, Silva LC, Cruz RA. Manifestaçôes bucais das leucemias agudas na infância. Arq Bras Odontol. 2008;4(1):40-54. 
10. Epstein JB, Tsang AH, Warkentin D, Ship JA. The role of salivary function in modulating chemotherapy-induced oropharyngeal mucositis: a review of the literature. Oral Surg Oral Med Oral Pathol Oral Radiol Endod. 2002;94(1):39-44.

11. Pels E, Mielnik-Błaszczak M. Oral hygiene in children suffering from acute lymphoblastic leukemia living in rural and urban regions. Ann Agric Environ Med. 2012;19(3):529-33

12. de Mendonça RM, de Araújo M, Levy CE, Morari J, Silva RA, Yunes JA, et al. Prospective evaluation of HSV, Candida spp., and oral bacteria on the severity of oral mucositis in pediatric acute lymphoblastic leukemia. Support Care Cancer. 2012;20(5):1101-7.

13. Pereira Pinto L, de Souza LB, Gordón-Núnez MA, Soares RC, de Brito Costa EM, de Aquino AR, et al. Prevention of oral lesions in children with acute lymphoblastic leukemia. Int J Pediatr Otorhinolaryngol. 2006;70(11):1847-51.

14. Soares AF, Aquino AR, Carvalho CH, Nonaka CF, Almeida D, Pinto, LP. Frequency of oral mucositis and microbiological analysis in children with acute lymphoblastic leukemia treated with $0.12 \%$ chlorhexidine gluconate. Braz Dent J. 2011;22(4):312-6.

15. Costa EM, Fernandes MZ, Quinder LB, de Souza LB, Pinto LP. Evaluation of an oral preventive protocol in children with acute lymphoblastic leukemia. Pesqui Odontol Bras. 2003;17(2): 147-50,

16. Choi SE, Kim HS. Sodium bicarbonate solution versus chlorhexidine mouthwash in oral care of acute leukemia patients undergoing induction chemotherapy: a randomized controlled trial. Asian Nurs Res. 2012;6(2):60-6.

17. Mehdipour M, Taghavi Zenoz A, Asvadi Kermani I, Hosseinpour A. A comparison between zinc sulfate and chlorhexidine gluconate mouthwashes in the prevention of chemotherapy-induced oral mucositis. Daru. 2011;19(1):71-3.

18. Setiawan AS, Reniarti L, Oewen RR. Comparative effects of chlorhexidine gluconate and povidone iodine mouthwashes to chemotherapy induced oral mucositis in children with acute lymphoblastic leukemia. Int J of Oral Med Sci. 2006;5(1):1-5.

19. Macêdo TM, Campos TF, Mendes RE, França DC, Chaves GS, Mendonça KM. Função pulmonar de crianças com leucemia aguda na fase de manutenção da quimioterapia. Rev Paul Pediatr. 2014;32(4):320-5.

20. Sonis ST, O’Donnell KE, Popat R, Bragdon C, Phelan S, Cocks D, et al. The rela- tionship between mucosal cyclooxygenase-2 (COX-2) expression and experimental radiation-induced mucositis. Oral Oncol. 2004;40(2):170-6.

21. Sonis ST. Mucositis as a biological process: a new hypothesis for the development of chemotherapy-induced stomatotoxicity. Oral Oncol. 1998;34(1):39-43.

22. Dodd MJ, Larson PJ, Dibble SL, Miaskowski C, Greenspan D, MacPhail L, et al. Randomized clinical trial of chlorhexidine versus placebo for prevention of oral mucositis in patients receiving chemotherapy. Oncol Nurs Forum. 1996;23(6):921-7.

23. Epstein JB, Vickars L, Spinelli J, Reece D. Efficacy of chlorhexidine and nystatin rinses in prevention of oral complications in leukemia and bone marrow transplantation. Oral Surg Oral Med Oral Pathol.1992;73(5):682-9.

24. Hasenau C, Clasen BP, Roettger D. [Use of standardized oral hygiene in prevention and therapy of mucositis in patients treated with radiochemotherapy of head and neck neoplasm]. Laryngol Rhinol Otol. 1988;67(11):576-9. German.

25. Rahn R, Adamietz IA, Boettcher HD, Schaefer V, Reimer K, Fleischer W. Povidone-iodine to prevent mucositis in patients during antineoplastic radiochemotherapy. Dermatology. 1997;195(Suppl 2):57-61.

26. Pitten FA, Kiefer T, Buth C, Doelken G, Kramer A. Do cancer patients with chemotherapy-induced leukopenia benefit from an antiseptic chlorhexidine-based oral rinse? A double-blind, block-randomized, controlled study. J Hosp Infect. 2003;53(4):283-91.

27. Ferretti GA, Raybould TP, Brown AT, Macdonald JS, Greenwood M, Maruyama $\mathrm{Y}$, et al. Chlorhexidine prophylaxis for chemotherapy- and radiotherapy-induced stomatitis: a randomized double-blind trial. Oral Surg Oral Med Oral Pathol. 1990;69(3):331-8

28. Labarca JA, Leber AL, Kern VL, Territo MC, Brankovic LE, Bruckner DA, et al Outbreak of Stenotrophomonas maltophilia bacteremia in allogenic bone marrow transplant patients: role of severe neutropenia and mucositis. Clin Infect Dis. 2000;30(1):195-7.

29. Köstler WJ, Hejna M, Wenzel C, Zielinski C. Oral mucositis complicating chemotherapy and/or radiotherapy: options for prevention and treatment. CA Cancer J Clin. 2001;51(5):290-315

30. Kelner N, Castro JF. Laser de baixa intensidade no tratamento da mucosite oral induzida pela radioterapia: relato de casos clínicos. Rev Bras Cancerol. 2007;53(1):29-33. 